\title{
PENGARUH KUALITAS AUDIT DAN AUDITOR SWITCHING TERHADAP KECURANGAN PELAPORAN KEUANGAN: KEPEMILIKAN INSTITUSIONAL SEBAGAI VARIABEL MODER- ATING
}

TARMIZI ACHMAD (ㄴ_achmad@yahoo.com.au)

Jurusan Akuntansi, Fakultas Ekonomika dan Bisnis, Universitas Diponegoro, Indonesia

\begin{abstract}
A B S T R A C T
This study aims to examine the effect of audit quality and auditor switching on fraudulent financial reporting. This study also examined the effect of institutional ownership as a moderating variable in the relationship of audit quality and auditor switching to fraudulent financial reporting. The population of this research is all companies listed on the Indonesia Stock Exchange in 2010-2017. Based on purposive sampling produced a sample of 40 companies with a total of 320 observations. The results of hypothesis testing with the software program Eviews 10.0 indicate that there is a positive significant influence between auditors switching to fraudulent financial reporting. Furthermore, the results of this study prove that institutional ownership is able to weaken the relationship auditor switching to fraudulent financial reporting. The results of the subsequent research show that there is no negative significant influence between audit quality on fraudulent financial reporting and institutional ownership that is not able to strengthen the relationship of the audit quality to fraudulent financial reporting.

Keywords: Audit Quality, Auditor Switching, Fraudulent Financial Reporting, Institutional Ownership
\end{abstract}

Penelitian ini bertujuan untuk menguji pengaruh kualitas audit dan auditor switching terhadap kecurangan pelaporan keuangan. Penelitian ini juga menguji pengaruh kepemilikan institusional sebagai variabel pemoderasi pada hubungan kualitas audit dan auditor switching terhadap kecurangan pelaporan keuangan. Populasi penelitian ini adalah seluruh perusahaan yang terdaftar di Bursa Efek Indonesia pada tahun 2010-2017. Berdasarkan purposive sampling menghasilkan sampel sebanyak 40 perusahaan dengan total 320 observasi. Hasil uji hipotesis dengan program software Eviews 10.0 menunjukkan bahwa terdapat pengaruh signifikan positif antara auditor switching terhadap kecurangan pelaporan keuangan. Selanjutnya, hasil penelitian ini membuktikan bahwa kepemilikan institusional mampu memperlemah pada hubungan auditor switching terhadap kecurangan pelaporan keuangan. Hasil penelitian selanjutnya menunjukkan tidak terdapat pengaruh signifikan negatif antara kualitas audit terhadap kecurangan pelaporan keuangan dan kepemilikan institusional juga tidak mampu memperkuat pada hubungan kualitas audit terhadap kecurangan pelaporan keuangan.

Kata Kunci: Kualitas Audit; Auditor Switching; Kecurangan Pelaporan Keuangan; Kepemilikan Institusional.

\section{PENDAHULUAN}

Laporan keuangan menjadi tolok ukur bagi pihak internal dan eksternal perusahaan untuk menilai kinerja suatu perusahaan. Tujuan umum dari laporan keuangan yaitu untuk memberikan informasi tentang posisi keuangan, kinerja dan arus kas perusahaan serta menunjukkan akuntabilitas manajemen dalam penggunaan sumber daya yang dipercayakan kepada mereka. Adanya penilaian kinerja perusahaan mendorong manajemen untuk menjalankan kegiatan operasional perusahaan seoptimal mungkin dengan tujuan memberikan informasi kepada pemangku kepentingan bahwa kondisi perusahaan dalam keadaan baik. Namun, upaya yang dilakukan manajemen kadang cenderung mengarah pada kecurangan pelaporan keuangan. Hal ini menyebabkan informasi yang terkandung dalam laporan keuangan menjadi tidak relevan bagi para pemangku kepentingan sebagai dasar pengambilan keputusan ekonomi. Kecurangan pelaporan keuangan 
merupakan kecurangan yang paling rendah proporsinya jika dibandingkan dengan jenis kecurangan yang lain seperti korupsi dan penyalahgunaan aset, namun dampak kerugian yang diakibatkan justru merupakan yang terbesar (Association of Certified Fraud Examiners, 2018). Meningkatnya kecurangan pelaporan keuangan perusahaan telah meningkatkan kekhawatiran pengguna laporan keuangan seperti auditor, investor, dan kreditor. Keruntuhan perusahaan-perusahaan internasional seperti World Com, Enron, dan Global Crossing disebabkan adanya kecurangan laporan keuangan. Di Indonesia, baru baru ini berdasarkan hasil pemeriksaan Otoritas Jasa Keungan (OJK), PT Sunprima Nusantara Pembiayaan (SNP) Finance terindikasi telah menyajikan laporan keuangan yang tidak sesuai dengan kondisi keuangan perusahaan sebenarnya dan berpotensi mengalami gagal bayar atau kredit bermasalah, sehingga menyebabkan kerugian banyak pihak (CNN, 2018).

Laporan keuangan yang berkualitas, relevan, dapat dipercaya dan diandalkan serta terbebas dari salah saji material merupakan sumber informasi untuk pengambilan keputusan. Laporan keuangan yang berkualitas dihasilkan dari audit yang dilakukan secara efektif oleh auditor yang berkualifikasi dengan asumsi bahwa untuk menjaga kredibilitasnya, auditor menjadi lebih berhati-hati dalam melakukan proses audit untuk mendeteksi salah saji atau segala bentuk kecurangan baik disengaja (fraud) maupun tidak disengaja (error). Auditor yang berkualifikasi akan melakukan audit yang berkualitas juga. Beberapa penelitian sebelumnya membuktikan adanya hasil penelitian yang tidak konsisten. Hasil penelitian Guna dan Herawaty, (2010) membuktikan bahwa kualitas audit memiliki pengaruh yang signifikan terhadap kecurangan pelaporan keuangan. Hal ini sejalan dengan hasil penelitian Smaili dan Labelle, (2009) yang menunjukkan bahwa auditor BIG4 memiliki kemampuan yang lebih baik untuk menghambat kecurangan daripada KAP Non-BIG4. Hasil penelitian ini juga konsisten dengan penelitian yang dilakukan oleh Gerayli et al. (2011) menemukan efek negatif yang signifikan antara ukuran KAP sebagai proksi dari kualitas audit terhadap kecurangan perlaporan keuangan. Namun demikian Handayani et al. (2009) menemukan bahwa kualitas audit tidak berpengaruh signifikan terhadap kecurangan. Selanjutnya, hasil penelitian Werastuti, (2015) menemukan bahwa auditor switching tidak berpengaruh terhadap kecurangan pelaporan keuangan. Hal senada juga disampaikan Suyanto, (2009) menemukan auditor switching tidak berpengaruh secara signifikan terhadap kecurangan pelaporan keuangan. Namun demikian, hasil penelitian Septriani, (2018) menyatakan auditor switching berpengaruh secara signifikan terhadap kecurangan pelaporan keuangan.

Kepemilikan institusional merupakan saham perusahaan yang dimiliki oleh institusi keuangan yang terdiri dari perusahaan asuransi, bank, dan invesment banking (Miyajima dan Hoda, 2015). Kepemilikan institusional dapat meningkatkan sistem kontrol perusahaan untuk meminimalisir perilaku kecurangan pelaporan keuangan oleh pihak manajemen. Kepemilikan institusional sebagai pemegang saham besar dalam fungsi pemantauan tata kelola perusahaan memiliki potensi membatasi masalah agensi yang terkait dengan pemisahan kepemilikan dan kontrol di perusahaan (Rezaee, 2007). Dengan demikian, kepemilikan institusional dapat memainkan peran penting dalam mengurangi informasi asimetri antara manajemen dan pemegang saham. Sehingga, dapat mengurangi kecurangan pelaporan keuangan yang dilakukan oleh pihak manajemen. Kepemilikan institusional dipilih sebagai variabel pemoderasi pada penelitian ini untuk memupus keraguan stakeholders terhadap informasi kecurangan pelaporan keuangan perusahaan di Indonesia. Dengan dipilihnya kepemilikan institusional sebagai variabel pemoderasi diharapkan mampu memperkuat hubungan antara kualitas audit terhadap kecurangan pelaporan keuangan. Selanjutnya juga untuk memperlemah pada hubungan auditor switching terhadap kecurangan pelaporan keuangan. Kepemilikan institusional dapat menjadi mekanisme good corporate governance. 
Kepemilikan institusional merupakan salah satu mekanisme good corporate governance yang dapat membantu mengatasi konflik dari adanya asimetri informasi antara manajemen dan pemilik perusahaan (Rezaee, 2007). Dengan kepemilikan intitusional semakin tinggi maka dapat menekan manajemen supaya berusaha dengan lebih optimal untuk menjaga going concern pada aspek keuangan, salah satunya dengan mengurangi kecurangan pelaporan keuangan sehingga kepercayaan para stakeholders tetap terjaga. Semakin tinggi kepemilikan institusional, maka kewenangan dan pemantauannya juga semakin tinggi. Selanjutnya, dapat menentukan kebijakan dalam mengurangi kecurangan pelaporan keuangan dengan cara meningkatkan kualitas audit sehingga dapat mendeteksi kecurangan pelaporan keuangan dan tingkat kecurangan pelaporan keuangan menjadi semakin rendah. Semakin tinggi kepemilikan institusional, diharapkan pemantauan dalam setiap keputusan manajemen dapat lebih terkontrol. Semakin tingginya kepemilikan institusional juga dapat berperan menekan auditor switching, hal ini dikarenakan sebagai pemilik saham yang besar dalam perusahaan. Dengan menekan dan menjaga frekuensi auditor switching secara wajib, diharapkan kecurangan pelaporan keuangan yang terjadi dapat terdeteksi dan terungkap. Dengan demikian, jika perusahaan melakukan kecurangan pelaporan keuangan membutuhkan banyak pertimbangan dan menjadi takut terungkap sehingga kecurangan pelaporan keuangan semakin menurun dan tidak terjadi kembali.

Berdasarkan fenomena dan ketidakkonsistenan berbagai penelitian diatas maka kecurangan pelaporan keuangan sangat menarik untuk dikaji lebih lanjut. Tujuan dari penelitian ini adalah untuk menguji pengaruh kualitas audit dan auditor switching terhadap kecurangan pelaporan keuangan dan kepemilikan institusional sebagai variabel moderasi pada hubungan antara kualitas audit dan auditor switching terhadap kecurangan pelaporan keuangan. Pada bagian pertama penelitian ini, diuraikan tentang fenomena kecurangan pelaporan keuangan dan berbagai hasil penelitian yang menguji kualitas audit dan auditor switching terhadap kecurangan pelaporan keuangan serta tujuan penelitian. Pada bagian kedua, diuraikan tentang tinjauan pustaka dan pengembangan hipotesis. Pada bagian ketiga dijelaskan tentang metode penelitian, populasi, metode pemilihan sampel, metode analisis, dan definisi operasional variabel serta pengukurannya. Pada Bagian keempat, dijelaskan tentang hasil pengujian hipotesis dan pembahasannya. Pada bagian akhir penelitian ini, dijelaskan tentang simpulan, keterbatasan dan saran untuk penelitian yang akan datang.

\section{TINJAUAN PUSTAKA DAN PENGEM- BANGAN HIPOTESIS}

\section{Kecurangan Pelaporan Keuangan}

Menurut Association of Certified Fraud Examiners, (2018) kecurangan merupakan bahaya laten yang mengancam dunia. Klasifikasi kecurangan dapat dibagi menjadi 3, yaitu: (1) Kecurangan pelaporan keuangan yang meliputi tindakan manipulasi keuangan dalam penyajian laporan keuangan untuk menutupi kondisi perusahaan yang sebenarnya. (2) Penyalahgunaan aset (asset misappropriation) yang terdiri atas kecurangan kas dan kecurangan persediaan dan aset lain. (3) Korupsi, terdiri atas pertentangan kepentingan (conflict of interest), penyuapan, hadiah tidak sah (gratifikasi ilegal), dan pemerasan ekonomi (economy exortion) (Association of Certified Fraud Examiners, 2018). The Treadway Commission mendefinisikan kecurangan pelaporan keuangan sebagai tindakan yang sembrono, atau kelalaian yang menyebabkan laporan keuangan material dan menyesatkan (Rezaee dan Davani, 2013).

Menurut Wells, (2011) kecurangan pelaporan keuangan meliputi beberapa modus seperti: (1) Pemalsuan, manipulasi keuangan atau dokumen pendukung. (2) Menghilangkan informasi yang signifikan sebagai sumber pelaporan keuangan. (3) Implementasi yang salah terhadap prinsip akuntansi, prosedur atau kebijakan dalam pengukuran, pengakuan, pelaporan dan pengungkapan peristiwa ekonomi maupun transaksi bisnis. (4) Menghilangkan secara 
sengaja informasi yang seharusnya diungkapkan terkait prinsip dan kebijakan akuntansi dalam pembuatan laporan keuangan. Proses penyajian laporan keuangan yang adil, jujur, dan berkualitas adalah tanggung jawab manajemen (Rezaee dan Davani, 2013). Menurut Association of Certified Fraud Examiners, (2018) kecurangan pelaporan keuangan merupakan kekeliruan yang disengaja dari jumlah maupun pengungkapan dalam laporan keuangan untuk menipu pengguna laporan keuangan. Kecurangan pelaporan keuangan mencakup manipulasi, pemalsuan, atau perubahan informasi atau dokumen dari laporan keuangan yaitu tidak menyajikan atau dengan sengaja menghilangkan kejadian, transaksi, dan informasi penting dari laporan keuangan.

\section{Agency Theory}

Para pionir teori agensi Jensen dan Meckling, (1976), menganalisis hubungan antara prinsipal dan agen. Hubungan dan agen utama ini cenderung menciptakan perbedaan antara pelaku dan agen, karena pada prinsipnya manusia berusaha memaksimalkan utilitas mereka untuk kepentingan mereka sendiri. Posisi agen sebagai manajer perusahaan lebih menguntungkan daripada prinsipal, karena agen mengetahui informasi internal dan prospek perusahaan di masa depan. Manajer sebagai agen wajib memberikan informasi tentang kondisi perusahaan kepada prinsipal. Namun, informasi yang disampaikan terkadang tidak sesuai dengan kondisi perusahaan yang sebenarnya. Kondisi ini dikenal sebagai informasi asimetri. Berdasarkan teori keagenan, perbedaan kepentingan antara manajer dan pemegang saham menimbulkan konflik keagenan. Salah satu cara untuk mengurangi konflik antara prinsipal dan dapat dilakukan dengan meningkatkan kepemilikan institusional perusahaan. Tindakan yang dilakukan manajemen akibat dari masalah agensi antara agen dan prinsipal seringkali berkaitan erat dengan kecurangan pelaporan keuangan. Perusahaan yang melakukan kecurangan lebih sering menggunakan kualitas audit yang rendah dan melakukan auditor switching, karena manajemen perusahaan cenderung berusaha mengurangi kemungkinan pendeteksian oleh auditor yang lama terkait kecurangan pelaporan keuangan. Kecenderungan ini mendorong perusahaan untuk menggunakan kualitas audit yang rendah dan melakukan auditor switching secara sukarela untuk menutupi kecurangan pelaporan keuangan.

Kepemilikan institusional dapat membatasi pihak managemen perusahaan untuk melakukan hal-hal yang tidak sejalan dengan kepentingan pemegang saham yang selanjutnya dapat mengurangi agency cost (Rezaee, 2007). Keberadaan investor institusional dapat meminimalisir insentif bagi perilaku opportunistik manajer dengan memberikan fungsi pemantauan dan pengendalian yang lebih ketat dan efektif terhadap perlaku manajerial dibandingkan dengan investor perseorangan (Shah et al., 2009). Struktur kepemilikan dalam perusahaan menimbulkan motivasi yang berbeda dalam mengawasi dan menjalankan manajemen perusahaan. Secara umum, institusi menyerahkan tanggung jawab kepada divisi tertentu dalam mengelola investasi suatu perusahaan. Kepemilikan institusional dapat melakukan pengawasan maupun pemantauan secara professional dan rutin dalam perusahaan karena kepemilikan saham institusional memiliki wewenang dan kekuatan untuk dapat meningkatkan kinerja secara efektif sekaligus mencegah terjadinya kecurangan pelaporan keuangan dengan cara meningkatkan kualitas auditnya dan mengurangi auditor switching. Dengan kepemilikan saham institusional, dapat meningkatkan pengawasan terhadap kinerja manajemen perusahaan supaya lebih optimal. Tindakan pencegahan kecurangan harus dilakukan untuk dapat mencapai tujuan perusahaan dan membuat reputasi perusahaan menjadi baik (Pamungkas et al., 2017).

\section{Pengembangan Hipotesis}

Pengaruh Kualitas Audit terhadap Kecurangan Pelaporan Keuangan

Penelitian kualitas audit terkonsentrasi pada perbedaan pemilihan jasa audit yaitu antara perusahaan yang menggunakan KAP BIG4 (Deloitte, PWC, Ernst dan Young, KPMG) dan KAP Non-BIG4. Hal ini dikarenakan, KAP BIG4 dianggap memiliki ke- 
mampuan lebih handal dalam mendeteksi dan mengungkap kecurangan yang dilakukan oleh pihak manajemen perusahaan dibandingkan dengan KAP Non-BIG4. Hal ini dibuktikan Smaili dan Labelle, (2009) yang menunjukkan bahwa auditor yang bekerja pada KAP BIG4 memiliki kemampuan lebih dalam mendeteksi kecurangan jika dibandingkan dengan KAP Non-BIG4. Perusahaan yang menggunakan kualitas auditor yang semakin tinggi dapat mencegah emiten dari kecurangan dalam menyajikan laporan keuangan yang tidak relevan kepada publik dan pengguna laporan keuangan.

Menurut Lennox dan Pittman, (2010) perusahaan yang menggunakan KAP BIG4 mempunyai kemampuan kualitas audit yang lebih dalam mendeteksi kecurangan jika dibandingkan dengan perusahaan yang diaudit oleh KAP Non-BIG4. Kualitas audit yang tinggi bertindak sebagai pencegahan dan mengurangi kesempatan yang efektif untuk melakukan kecurangan (Gerayli et al., 2011). Reputasi manajemen menjadi runtuh dan nilai perusahaan menurun jika kecurangan ini dapat terdeteksi dan terungkap. Kualitas audit suatu perusahaan tinggi, maka kecurangan pelaporan keuangan semakin turun. Begitupun sebaliknya, jika kualitas audit suatu perusahaan rendah, maka kecurangan pelaporan keuangan menjadi semakin tinggi. Berdasarkan uraian tersebut, hipotesis penelitian ini:

H1: Kualitas audit berpengaruh negatif terhadap kecurangan pelaporan keuangan

\section{Pengaruh Auditor Switching terhadap Kecurangan Pelaporan Keuangan}

SAS No. 99 menyatakan bahwa perusahaan yang melakukan auditor switching secara sukarela dapat menjadi indikasi terjadinya kecurangan. Hal tersebut senada dengan Skousen et al. (2009) yang menyatakan bahwa dengan adanya auditor switching mengindikasikan adanya kecurangan pada perusahaan tersebut. Auditor sebelumnya mungkin dapat mendeteksi kemungkinan kecurangan oleh manajemen, baik secara langsung maupun tidak langsung. Sebelum indikasi kecurangan tersebut terungkap, perusahaan segera melakukan auditor switching secara sukarela. Semakin tingginya auditor switching secara sukarela maka kecurangan pelaporan keuangan semakin meningkat. Hal ini disebabkan auditor baru masih membutuhkan waktu untuk beradaptasi dan mendalami perusahaan tersebut sehingga tidak dapat secara langsung mendeteksi jika pihak manajemen perusahaan melakukan kecurangan pelaporan keuangan dan auditor belum akrab dengan auditee. Auditor merupakan pengawas penting dalam laporan keuangan. Dengan keahlian para auditor, kita dapat mengetahui bahwa beberapa perusahaan melakukan kecurangan pelaporan keuangan. Ketika perusahaan menggunakan auditor yang baru/ pengganti, terjadi asimetri informasi antara perusahaan dan auditor. Hal ini dikarenakan auditor mempunyai informasi yang lebih sedikit ketika dibandingkan dengan informasi yang dimiliki manajemen tentang perusahaan.

Auditor sebelumnya mungkin dapat mendeteksi kemungkinan kecurangan yang dilakukan oleh manajemen secara langsung maupun tidak langsung. Namun, dengan auditor switching secara sukarela, kemungkinan kecurangan akan meningkat. Hasil penelitian yang dilakukan oleh Lou dan Wang, (2009) menyatakan bahwa perusahaan yang semakin sering melakukan auditor switching, maka dugaan kecurangan pelaporan keuangan juga semakin tinggi. Beberapa penelitian tersebut menunjukkan bahwa kecurangan pelaporan keuangan meningkat ketika auditor switching meningkat. Hal ini dikarenakan auditor ba$\mathrm{ru}$ /pengganti masih belum memahami kondisi perusahaan secara keseluruhan dan periode proses audit yang terbatas sehingga menjadi kendala dalam proses audit untuk mendeteksi kecurangan pelaporan keuangan. Jadi, perusahaan yang melakukan auditor switching secara sukarela memungkinkan kecurangan pelaporan keuangan semakin tinggi. Begitupun sebaliknya, perusahaan yang tidak melakukan auditor switching secara sukarela maka memungkinkan kecurangan pelaporan keuangan semakin rendah. Berdasarkan uraian tersebut, hipotesis penelitian ini:

H2: Auditor switching berpengaruh positif 
terhadap kecurangan laporan keuangan.

\section{Pengaruh Kepemilikan Institusional se- bagai Pemoderasi pada Hubungan Kuali- tas Audit terhadap Kecurangan Pelaporan Keuangan.}

Pemantauan dalam implementasi good corporate governance yang dilakukan investor institusional diharapkan dapat mendorong dan meningkatkan manajemen dalam memusatkan perhatiannya dalam kinerja persahaan sehingga dapat mengurangi perilaku manajemen untuk melakukan kecurangan pelaporan keuangan. Investor institusional merupakan kepemilikan saham yang mempunyai pengaruh yang cukup besar terhadap perusahaan dikarenakan kepemilikan sahamnya besar diperusahaan. Menurut Zureigat, (2011) kepemilikan institusional merupakan faktor penting pada perusahaanperusahaan di Yordania dalam memilih auditornya dan hasilnya menunjukkan bukti bahwa semakin tinggi persentase kepemilikan saham institusional maka semakin tinggi kualitas auditor dan memiliki laporan keuangan yang berkualtas tinggi sehingga terbebas dari kecurangan. Kepemilikan institusional mempunyai peran sangat penting untuk meminalisir konflik keagengan yang terjadi antara manajer dengan pemegang saham (Jensen dan Meckling, 1976).

Kepemilikan Institusional menunjukkan persentase dari total saham yang dimiliki oleh pihak institusional. Terdapat kemungkinan bahwa kepemilikan institusional yang rendah memiliki kecenderungan perilaku atau tindakan oportunistik yang harus diambil oleh manajemen. Begitupun sebaliknya, dengan persentase kepemilikan institusional yang tinggi, diharapkan investor institusional lebih memiliki kewenangan dan kekuatan dalam menekan serta mengendalikan pihak manajemen perusahaan. Dalam hal ini untuk menentukan dan merubah serta meningkatkan kualitas audit perusahaan yang sebelumnya menggunakan KAP non BIG4 menjadi KAP BIG4. Dengan cara mengganti KAP non BIG4 menjadi KAP BIG4 secara otomatis kualitas audit perusahaan akan menjadi tinggi. Dengan kualitas audit yang tinggi, diharapkan semakin mudah menemukan kecurangan pelaporan keuangan yang terjadi sehingga kecurangan akan menurun. Dengan demikian, dapat disimpulkan bahwa tingkat kepemilikan institusional yang semakin tinggi dapat memperkuat pada hubungan antara kualitas audit terhadap kecurangan pelaporan keuangan. Berdasarkan uraian diatas, maka rumusan hipotesis penelitian ini adalah sebagai berikut:

H3: Kepemilikan institusional memperkuat pengaruh kualitas audit terhadap kecurangan pelaporan keuangan.

Pengaruh Kepemilikan Institusional sebagai Pemoderasi pada Hubungan Auditor Switching terhadap Kecurangan Laporan Keuangan

Kebijakan mengenai rotasi Kantor Akuntan Publik dan rotasi Akuntan Publik di Indonesia diatur dalam Peraturan Pemerintah (PP) No.20 tahun 2015 tentang Praktik Akuntan Publik mengatur tentang pemberian jasa audit atas informasi keuangan historis terhadap suatu entitas oleh seorang Akuntan Publik dibatasi paling lama 5 (ima) tahun buku berturut-turut. Auditor sebelumnya atau yang lama dapat mendeteksi kemungkinan kecurangan pelaporan keuangan yang dilakukan oleh pihak manajemen, baik secara langsung maupun tidak langsung. Berdasarkan teori agensi, sering terdapat masalah antara perusahaan dan manajemen perusahaan yang disebabkan oleh adanya kepentingan yang berbeda dalam perusahaan. Isu yang menarik adalah intensif dalam mengawasi kinerja perusahaan (Jensen dan Meckling, 1976).

Kepemilikan institusional mempunyai peran penting dalam melawan tindak kecurangan dan korupsi melalui kebijakan investasi dan membantu menetapkan standar perusahaan (Santiso, 2016). Kepemilikan institusional dianggap dapat mengatasi masalah dari agen yang selalu terjadi, semakin tinggi persentase kepemilikan saham investor institusional akan mendorong mengawasan dan pemantauan menjadi semakin efektif karena dapat mengendalikan perilaku oportunis 
yang dilakukan manajemen perusahaan. Kepemilikan institusional berfungsi sebagai mekanisme pengawasan yang efektif, mencegah kecurangan dan meningkatkan tata kelola perusahaan dikarenakan investor institusional ikut dalam proses pengambilan keputusan strategik (Aggarwal, $\mathrm{Hu}$, dan Yang, 2014). Kepemilikan institusional yang semakin meningkat menjadikan wewenang dan kekuatan untuk menekan manajemen perusahaan melakukan auditor switching secara sukarela. Dengan tidak adanya auditor switching secara sukarela atau tidak terjadi perpindahan auditor dalam masa kontraknya, auditor yang lama dapat mengetahui potensi dan bahkan kecurangan pelaporan keuangan yang terjadi. Dengan demikian, kecurangan pelaporan keuangan dapat terungkap sehingga menurunkan tingkat kecurangan pelaporan keuangan perusahaan. Perusahaan dengan tingkat kepemilikan saham institusional semakin besar, maka tidak terjadi auditor switching secara sukarela sehingga kecurangan pelaporan keuangan semakin rendah. Berdasarkan uraian tersebut, peneliti merumuskan hipotesis sebagai berikut:

H4: Kepemilikan institusional memperlemah pengaruh auditor switching terhadap kecurangan pelaporan keuangan

\section{METODE PENELITIAN \\ Populasi dan Sampel}

Populasi dalam penelitian ini adalah seluruh perusahaan yang terdaftar di Bursa Efek Indonesia (BEI). Penelitian ini menggunakan metode penelitian kuantitatif. Penelitian ini menggunakan data sekunder yaitu laporan tahunan perusahaan yang telah diaudit. Metode pengumpulan data menggunakan annual report yang diperoleh dari data base Bloomberg, www.idx.co.id dan situs web perusahaan serta Indonesian Capital Market Directory (ICMD) pada 2010-2017. Teknik pengambilan sampel pada penelitian ini menggunakan metode purposive sampling yaitu sampel yang dipilih berdasarkan beberapa kriteria tertentu berdasarkan tujuan penelitian yang disajikan pada Tabel 1 .

Kriteria pengambilan sampel pada penelitian ini adalah sebagai berikut:

1. Seluruh Perusahaan yang terdaftar di Bursa Efek Indonesia dan mempublikasikan laporan tahunan yang diaudit secara lengkap dan tidak mengalami delisting selama periode pengamatan selama periode 2010-2017;

2. Perusahaan yang menerbitkan laporan tahunan selama 8 tahun berturut-turut dari tahun 2010-2017 dalam bentuk Rupiah Indonesia (Rp).

3. Perusahaan yang memiliki data lengkap dan terkait dengan semua variabel penelitian.

\section{Metode Analisis Data}

Pengujian hipotesis dilakukan menggunakan model binary logistic regression dengan menggunakan balance data panel yaitu jumlah perusahaan selama tahun pengamatan dengan data lengkap. Balance data panel merupakan penggabungan data time series dan cross section. Pengujian hubungan variabel independen dan dependen menggunakan Software Eviews 10.0. Variabel kecurangan (fraud) menggunakan dummy yang dikategorikan menjadi dua, yaitu kode 1 (satu) untuk perusahaan fraud dan 0 (nol) untuk perusahaan non-fraud.

Tabel 1.

Teknik Pengambilan Sampel

\begin{tabular}{|c|c|c|}
\hline No & Kriteria & Jumlah \\
\hline 1 & $\begin{array}{l}\text { Seluruh Perusahaan yang ter- } \\
\text { daftar di Bursa Efek Indonesia } \\
\text { dan mempublikasikan laporan } \\
\text { tahunan yang diaudit secara } \\
\text { lengkap dan tidak mengalami } \\
\text { delisting selama periode } \\
\text { pengamatan selama periode } \\
\text { 2010-2017: }\end{array}$ & 555 \\
\hline 2 & $\begin{array}{l}\text { Perusahaan yang tidak mener- } \\
\text { bitkan laporan tahunan selama } \\
8 \text { tahun berturut-turut dari } \\
\text { tahun } 2010-2017 \text { dalam ben- } \\
\text { tuk Rupiah Indonesia (Rp). }\end{array}$ & (147) \\
\hline 3 & $\begin{array}{l}\text { Perusahaan yang tidak mem- } \\
\text { iliki data lengkap dan terkait } \\
\text { dengan semua variabel }\end{array}$ & (368) \\
\hline & $\begin{array}{l}\text { Jumlah Perusahaan yang me- } \\
\text { menuhi kreteria Sampling }\end{array}$ & 40 \\
\hline 4 & $\begin{array}{l}\text { Jumlah Observasi } 8 \text { tahun } \\
(2010-2017)\end{array}$ & 320 \\
\hline
\end{tabular}


Definisi Operasional dan Pengukuran Variabel

Kecurangan Pelaporan Keuangan (Variabel dependen)

Variabel dependen (Y) kecurangan pelaporan keuangan diproksikan dengan model M-Score Beneish dan Nichols, (2012) yang disajikan pada Tabel 2. Sesuai penelitian Beneish dan Nichols, (2012) model $M$-Score terdiri dari 8 variabel, yaitu: Days Sales in Receivables Index (DSRI), Gross Margin Index (GMI), Asset Quality Index (AQI), Sales Growth Index (SGI), Depreciation Index (DEPI), Sales General And Administrative Expenses Index (SGAI), Leverage Index (LEVI), and Total Accruals to Total Assets Index (TATA). Setelah melakukan perhitungan kedelapan indeks tersebut, kemudian diformulasikan dalam rumus MBeneish Score Model.

Jika M-Score menunjukkan hasil > 2,22, maka hasil tersebut menunjukkan adanya indikasi kecurangan pelaporan keuangan pada perusahaaan, jika M-Score menunjukkan hasil $<2,22$, maka hasil tersebut menunjukkan tidak adanya indikasi kecurangan pelaporan keuangan pada pe- rusahaan tersebut (Beneish dan Nichols, 2012).

Perhitungan matematis untuk mendapatkan nilai M-Benesih Score Model, yaitu:

$$
\begin{aligned}
\text { M Score }= & -4,840+0,920 \mathrm{DRSI}+0,528 \mathrm{GMI}+ \\
& 0,404 \mathrm{AQI}+0,892 \mathrm{SGI}+ \\
& 0,115 \mathrm{DEPI}-0,172 \text { SGAI } \quad \\
& 0,327 \mathrm{LVGI}+4,697 \mathrm{TATA}
\end{aligned}
$$

\section{Kualitas Audit dan Auditor Switching (Variabel Independen)}

Kualitas audit dalam beberapa referensi didasarkan pada kelayakan praktik audit dengan standar audit yang mencakup standar umum, standar kerja lapangan dan standar pelaporan. Variabel kualitas audit menggunakan proxy skala auditor dan pengukurannya dengan variabel dummy. Jika entitas menggunakan KAP BIG4 maka diberi nilai 1. Jika entitas menggunakan non-BIG4 KAP maka nilainya adalah 0 . Auditor Switching dalam penelitian ini dapat dinilai sebagai upaya untuk menghilangkan jejak kecurangan yang ditemukan oleh auditor sebelumnya. Kecenderungan ini mendorong perusahaan untuk mengganti auditor independen mereka untuk menutupi

\begin{tabular}{|c|c|c|}
\hline $\mathbf{N}$ & Rasio & Proxy \\
\hline 1 & Days Sales Receiv- & (Net Receivables $t$ / Sales $t$ ) / Net Receivables $t$-1 / Sales $t$-1) \\
\hline 2 & $\begin{array}{l}\text { Gross Margin In- } \\
\operatorname{dex}(G M I)\end{array}$ & $\begin{array}{l}{[(\text { Sales } t-1-\text { Cost Of Goods Sold } t-1) / \text { Sales } t-1] /[\text { (Sales } t-} \\
\text { Cost Of Goods Sold } t) / \text { Sales } t]\end{array}$ \\
\hline 3 & $\begin{array}{l}\text { Asset Quality In- } \\
\operatorname{dex}(A Q I)\end{array}$ & $\begin{array}{l}\text { [Total Assets } t \text {-(Current Assets } t+\text { Plant, Property \& Equip- } \\
\text { ment } t) / \text { Total Assets } t] /[\text { Total Assets } t-1-(\text { Current Assets } t-1 \\
+ \text { Plant, Property \& Equipment } t-1) / \text { Total Assets } t-1)]\end{array}$ \\
\hline 4 & $\begin{array}{l}\text { Sales Growth In- } \\
\operatorname{dex}(S G I)\end{array}$ & Sales $t /$ Salest -1 \\
\hline 5 & $\begin{array}{l}\text { Depreciation Index } \\
\text { (DEPI) }\end{array}$ & $\begin{array}{l}\text { [Depreciation } t-1 / \text { (Plant, Property \& Equipment } t-1+\text { Depre- } \\
\text { ciation } t-1)] /[\text { Depreciation } t / \text { (Plant, Property \& Equipment } t \\
+ \text { Depreciation } t)]\end{array}$ \\
\hline & $\begin{array}{l}\text { SG\&A Expense In- } \\
\operatorname{dex}(S G A I)\end{array}$ & $\begin{array}{l}\text { (Selling General \& Administrative Expense } t / \text { Sales } t \text { ) } \\
\text { (Selling General \& Administrative Expense } t-1 / \text { Sales } t-1 \text { ) }\end{array}$ \\
\hline 6 & $\begin{array}{l}\text { Leverage index } \\
\text { (LVGI) }\end{array}$ & $\begin{array}{l}\text { [(Current Liabilities } t+\text { Total Long Term Debt } t) / \text { Total As- } \\
\text { sets } t] /[(\text { Current Liabilities } t-1+\text { Total Long Term Debt } t-1) / \\
\text { Total Assets } t-1]\end{array}$ \\
\hline 7 & $\begin{array}{lr}\text { Total } & \text { Accruals to } \\
\text { Total } & \text { Assets } \\
\text { (TATA) }\end{array}$ & $\begin{array}{l}\text { (Income from Continuing Operations } t \text { - Cash Flows from Op- } \\
\text { erations } t \text { ) / Total Assets } t\end{array}$ \\
\hline
\end{tabular}
kecurangan dalam perusahaan. Kebijakan

Tabel 2.

Rasio Keuangan untuk Mengukur M-Beniesh Score Model 
mengenai rotasi Kantor Akuntan Publik dan rotasi Akuntan Publik di Indonesia diatur dalam Peraturan Menteri Keuangan (PMK) No.7 tahun 2008 tentang Praktik Akuntan Publik mengatur tentang pemberian jasa audit atas informasi keuangan historis terhadap suatu entitas oleh seorang Akuntan Publik dibatasi paling lama 3 (tiga) tahun buku berturut-turut. Selanjutnya, Peraturan Pemerintah (PP) No.20 tahun 2015 tentang Praktik Akuntan Publik mengatur tentang pemberian jasa audit atas informasi keuangan historis terhadap suatu entitas oleh seorang Akuntan Publik dibatasi paling lama 5 (ima) tahun buku berturut-turut. Definisi Operasionalisasi Variabel disajikan pada Tabel 3.

\section{Metode Analisis Data}

Bentuk Persamaan dalam penelitian ini yaitu menggunakan dengan rumus:

FRAUD $=\alpha+\beta 1 \mathrm{AQ}+\beta 2 \mathrm{AS}+\beta 3$ InstOwn + $\beta 4 \mathrm{AQ} *$ InstOwn + $\beta 5 \mathrm{As} *$ InstOwn + $\beta 6 \mathrm{LOG} \mathrm{TA}+\beta 7 \mathrm{LEV}+\beta 8 \mathrm{ROA}+\beta 9$ $\mathrm{CR}+e$

Keterangan:

FRAUD : Variabel dummy, kode 1 (satu) untuk perusahaan yang melakukan kecurangan pelaporan keuangan, kode 0 (nol) untuk yang tidak melakukan kecurangan pelaporan keuangan.

$\alpha \quad$ : Konstanta

$\beta \quad$ : Variabel koefisien

AQ : Variabel dummy, kode 1 (satu) untuk perusahaan yang menggunakan KAP BIG4, kode 0 (nol) untuk perusahaan yang menggunakan KAP Non-BIG4

AS : Variabel dummy, Kode 1 (satu) untuk perusahaan yang melakukan rotasi akuntan publik kurang dari 3 tahun (rotasi secara sukarela), kode 0 (nol) untuk perusahaan yang melakukan rotasi akuntan publik 3 tahun (rotasi secara

Tabel 3.

Operasionalisasi Variabel

\begin{tabular}{|c|c|c|}
\hline No & Nama Variabel & Pengukuran Variabel \\
\hline 1 & $\begin{array}{l}\text { Kecurangan Pelaporan } \\
\text { Keuangan (Variabel } \\
\text { Dependen) }\end{array}$ & $\begin{array}{l}\text { Variabel dummy, Kode } 1 \text { (satu) untuk perusahaan yang } \\
\text { melakukan kecurangan pelaporan keuangan, kode } 0 \\
\text { (nol) untuk yang tidak melakukan kecurangan } \\
\text { pelaporan keuangan. }\end{array}$ \\
\hline 2 & $\begin{array}{l}\text { Kualitas Audit } \\
\text { (Variabel Independen) }\end{array}$ & $\begin{array}{l}\text { Variabel dummy, kode } 1 \text { (satu) untuk perusahaan yang } \\
\text { menggunakan KAP BIG4, kode } 0 \text { (nol) untuk perus- } \\
\text { ahaan yang menggunakan KAP Non-BIG4. }\end{array}$ \\
\hline 3 & $\begin{array}{l}\text { Auditor Switching } \\
\text { (Variabel Independen) }\end{array}$ & $\begin{array}{l}\text { Variabel dummy, Kode } 1 \text { (satu) untuk perusahaan yang } \\
\text { melakukan rotasi akuntan publik kurang dari } 3 \text { tahun } \\
\text { (rotasi secara sukarela) pada tahun 2010-2015 dan } \\
\text { melakukan rotasi akuntan publik kurang dari } 5 \text { tahun } \\
\text { (rotasi secara sukarela) pada tahun } 2016 \text { dan } 2017 \text {. } \\
\text { Kode } 0 \text { (nol) untuk perusahaan yang melakukan rotasi } \\
\text { akuntan publik } 3 \text { tahun (rotasi secara wajib) selama } \\
\text { tahun } 2010-2015 \text { dan melakukan rotasi akuntan pub- } \\
\text { lik } 5 \text { tahun (rotasi secara wajib) selama tahun } 2016 \\
\text { dan } 2017\end{array}$ \\
\hline 4 & $\begin{array}{l}\text { Kepemilikan Institusional } \\
\text { (Variabel Moderating) }\end{array}$ & $\begin{array}{l}\text { (Total kepemilikan saham oleh institusional) / (Total } \\
\text { saham yang beredar) X100\%. }\end{array}$ \\
\hline 5 & $\begin{array}{l}\text { Ukuran perusahaan } \\
\text { (Variabel Kontrol) }\end{array}$ & Log. Total Aset \\
\hline 6 & $\begin{array}{l}\text { Leverage (Variabel } \\
\text { Kontrol) }\end{array}$ & Total Hutang/ Total Modal \\
\hline 7 & $\begin{array}{l}\text { Profitabilitas } \\
\text { (Variabel Kontrol) }\end{array}$ & Laba Bersih/ Total Aset \\
\hline 8 & $\begin{array}{l}\text { Current Ratio (Variabel } \\
\text { Kontrol) }\end{array}$ & Total Aset Lancar/ Total Hutang Lancar \\
\hline
\end{tabular}


wajib).

InstOwn : Pemegang saham yang dimiliki institusional

Log TA : Logaritma Total Aset

LEV : Rasio Total Hutang atas Total Modal (DER)

ROA : Rasio laba bersih atas aset (ROA)

CR : Current Ratio

E : error

\section{ANALISIS DAN PEMBAHASAN}

Hasil pengujian statistik deskriptif pengolahan data pada penelitian ini menunjukkan sampel sebanyak 40 perusahaan pada periode 2010-2017 dengan total 320 observasi yang disajikan pada Tabel 4 .

Hasil pengujian deskriptif pada penelitian ini menjelaskan secara deskriptif terkait semua variabel penelitian. Berdasarkan Tabel 4. menunjukkan bahwa total observasi sebanyak 320 dengan variabel operasional yang memiliki mean lebih besar jika dibandingkan standar deviasi. Terdapat variabel operasional yang lebih kecil jika dibandingkan nilai standar deviasi yang membuktikan bahwa data variabel operasional pada penelitian ini menyebar atau bervariasi. Berdasarkan hasil pengujian pada Tabel 5. dapat diketahui bahwa persamaan binary logistic regression dengan balance data panel yang menjelaskan pengaruh kualitas audit dan auditor switching terhadap kecurangan pelaporan keuangan. Pengaruh moderasi kepemilikan institusional pada hubungan kualitas audit dan auditor switching terhadap kecurangan pelaporan keuangan serta variabel control ukuran perusahaan, leverage, profitabilitas dan current ratio pada seluruh perusahaan yang terdaftar di Bursa Efek Indonesia pada periode pengamatan selama tahun 2010 -2017 adalah sebagai berikut:

FRAUD $=\alpha+-6.857$ Kualitas Audit +19.487

Auditor Switching +-0153 Kepemilikan Institusional + $0.120 \quad$ Kualitas Audit*Kepemilikan Institusional + -0.123 Auditor Switching*Kepemilikan Institusional + -2.331 Ukuran Perusahaan + 1.079 Leverage + 0.378 Profitabilitas + -0.174 Current Ratio + e

Koefisien Determinasi (R2) pada penelitian ini dapat dilihat pada Tabel 5 . yaitu dengan melihat nilai McFadden $R$ squared yang merupakan ukuran yang analog dengan R2 atau pseudo R2 sebesar 0.931 atau 93.1\%. Hasil pengujian ini menunjukkan bahwa variabilitas variabel dependen yang dapat dijelaskan oleh variabilitas variabel independen sebesar 93.1\%. Semakin tinggi nilai koefisiensi determinasi atau mendekati angka nol berarti semakin baik kemampuan variabel independen dalam menjelaskan variabel dependen. Dengan demikian, maka variabel independen yang terdiri kualitas audit dan auditor switching dan variabel moderating kepemilikan institusional dapat mempengaruhi variabel dependen kecurangan pelaporan keuangan sebesar 0.931 atau $93.1 \%$, sedangkan sisanya yaitu 0.069 atau $6.9 \%$ dipengaruhi oleh variabel lain diluar variabel penelitian.

Berdasarkan Tabel 6. hasil uji Goodness-of-Fit Evaluation for Binary Specification Andrews and Hosmer-Lemeshow Test.

Tabel 4.

Statistik Deskriptif

\begin{tabular}{lcrrrrr}
\hline \multicolumn{1}{c}{ Variabel } & N & \multicolumn{1}{c}{ Mean } & Median & \multicolumn{1}{c}{ Max } & Min & Std. Dev \\
\hline $\begin{array}{l}\text { Kecurangan } \\
\text { Pelaporan Keuangan }\end{array}$ & 320 & 0.512 & 1.000 & 1.000 & 0.000 & 0.500 \\
Kualitas Audit & 320 & 1.800 & 1.000 & 1.000 & 0.000 & 0.400 \\
$\begin{array}{l}\text { Auditor Switching } \\
\text { Kepemilikan Insti- }\end{array}$ & 320 & 0.521 & 1.000 & 1.000 & 0.000 & 0.500 \\
tusional & 320 & 55.983 & 48.625 & 99.900 & 11.52 & 38.835 \\
Moderasi1 & & & & & & \\
Moderasi2 & 320 & 45.399 & 37.585 & 99.850 & 0.000 & 34.419 \\
Ukuran Perusahaan & 320 & 19.651 & 15.690 & 99.020 & 0.000 & 24.096 \\
Leverage & 320 & 4.166 & 4.166 & 5.470 & 0.037 & 0.445 \\
Profitabilitas & 320 & 1.101 & 0.770 & 5.670 & 0.150 & 0.991 \\
Current Ratio & 320 & 5.235 & 4.005 & 28.960 & 0.020 & 4.687 \\
\hline
\end{tabular}


Menunjukkan nilai sebesar 6.743 di atas 0.05. Jika nilai statistics HL Goodness of fit lebih besar dari 0.05, maka hipotesis nol tidak dapat ditolak dan berarti model mampu memprediksi nilai observasinya atau dapat dikatakan model dapat diterima karena cocok dengan data observasinya. Tampilan output software Eviews 10.0 pada penelitian ini menunjukkan bahwa $H L$ statistics sebesar 6.7436 dengan probabilitas signifikansi 0.4092 yang nilainya di atas 0.05. Dengan demikian, dapat disimpulkan bahwa model dapat diterima dan mampu memprediksi nilai observasi dikarenakan cocok dengan data observasinya.

\section{Kualitas Audit terhadap Kecurangan Pelaporan Keuangan}

Tabel 5 menunjukkan bahwa nilai signifikansi pada pengujian pengaruh kualitas audit terhadap kecurangan pelaporan keuangan sebesar 0.595 dengan nilai beta negatif -6.857. Dengan demikian, dapat disimpulkan bahwa hipotesis H1 ditolak. Hal ini menunjukkan bahwa kualitas audit tidak berpengaruh signifikan terhadap

Tabel 5.

Hasil Pengujian Hipotesis

\begin{tabular}{lccrc}
\hline \multicolumn{1}{c}{ Variabel } & Coefficient & $\begin{array}{l}\text { Std. Er- } \\
\text { ror }\end{array}$ & Z-Statistic & Prob. \\
\cline { 1 - 4 } Kualitas Audit & -6.857 & 12.916 & -0.530 & 0.595 \\
\hline Auditor Switching & 19.487 & 6.764 & 2.880 & 0.004 \\
Kepemilikan Institusional & -0.153 & 0.280 & -0.545 & 0.585 \\
Moderasi1 & 0.120 & 0.282 & 0.428 & 0.668 \\
Moderasi2 & -0.123 & 0.074 & -1.667 & 0.095 \\
Ukuran Perusahaan & -2.331 & 1.608 & -1.449 & 0.147 \\
Leverage & -1.079 & 0.505 & -2.133 & 0.032 \\
Profitabilitas & -0.378 & 0.155 & -2.435 & 0.014 \\
Current Ratio & -0.174 & 0.292 & -0.594 & 0.552 \\
McFadden R-squared & 0.931 & & & \\
\hline
\end{tabular}

Tabel 6.

Hasil Uji Goodness-of-Fit Test (Hosmer-Lemeshow)

\begin{tabular}{|c|c|c|c|c|c|c|c|c|}
\hline \multirow[t]{2}{*}{ No } & \multicolumn{2}{|c|}{ Quantile of Risk } & \multicolumn{2}{|c|}{$D e p=0$} & \multicolumn{2}{|c|}{$\operatorname{Dep}=1$} & \multirow{2}{*}{$\begin{array}{l}\text { Total } \\
\text { Obs }\end{array}$} & \multirow{2}{*}{$\begin{array}{c}\text { H-L Val- } \\
\text { ue }\end{array}$} \\
\hline & Low & High & Act & Expect & Act & Expect & & \\
\hline 1 & 3.E-08 & 0.0002 & 32 & 31.9977 & 0 & 0.00229 & 32 & 0.00229 \\
\hline 2 & 0.0002 & 0.0005 & 32 & 31.9894 & 0 & 0.01059 & 32 & 0.01059 \\
\hline 3 & 0.0005 & 0.0015 & 32 & 31.9696 & 0 & 0.03040 & 32 & 0.03043 \\
\hline 4 & 0.0016 & 0.0123 & 31 & 31.8401 & 1 & 0.15990 & 32 & 4.43599 \\
\hline 5 & 0.0139 & 0.7244 & 29 & 26.9647 & 3 & 5.03534 & 32 & 0.97634 \\
\hline 6 & 0.7677 & 0.9997 & 0 & 1.23382 & 32 & 30.7662 & 32 & 1.28330 \\
\hline 7 & 0.9997 & 1.0000 & 0 & 0.00406 & 32 & 31.9959 & 32 & 0.00406 \\
\hline 8 & 1.0000 & 1.0000 & 0 & 0.00053 & 32 & 31.9995 & 32 & 0.00053 \\
\hline 9 & 1.0000 & 1.0000 & 0 & 0.00011 & 32 & 31.9999 & 32 & 0.00011 \\
\hline 10 & 1.0000 & 1.0000 & 0 & 9.5E-06 & 32 & 32.0000 & 32 & 9.5E-06 \\
\hline Total & & & 156 & 156.000 & 164 & 164.000 & 320 & 6.743 \\
\hline$H-L$ & & & & & & & & \\
\hline $\begin{array}{l}\text { Statistic } \\
\text { Andrew }\end{array}$ & & & $\begin{array}{l}6.743 \\
188.3\end{array}$ & & & & & \\
\hline Statistic & & & 03 & & & & & \\
\hline
\end{tabular}


kecurangan pelaporan keuangan. Hasil penelitian Tsipouridou dan Spathis, (2012); Yasar, (2013) menyatakan bahwa tidak terdapat perbedaan hasil yang signifikan antara perusahaan yang diaudit oleh auditor BIG4 dan Non-BIG4 pada perusahaan yang melakukan earning management maupun kecurangan. Sebuah kantor akuntan publik besar, tidak akan lebih baik atau berkualitas daripada kantor akuntan yang lebih kecil jika sumber daya yang dimiliki tidak digunakan untuk memberikan pendapat secara independen. Seperti kasus Enron Andersen merupakan salah satu bukti. KAP Anderson ketika menjadi auditor Enron adalah sebuah kantor akuntan besar dengan sumber daya yang besar. Namun demikian, tidak terbukti digunakan secara independen.

KAP BIG4 dan Non-BIG4 masih perlu dipertanyakan sebagai pengukuran kualitas audit. Perusahaan yang menggunakan KAP BIG4 atau KAP Non-BIG4 mempunyai pengaruh yang tidak berbeda jauh sehubungan dengan proxy kualitas audit (Lawrence et al., 2011). Kasus yang barubaru ini terjadi di Indonesia misalnya dimana perusahaan PT Sunprima Nusantara Pembiayaan (SNP) Finance yang laporan keuangannya diaudit oleh KAP Deloitte (KAP BIG4) terindikasi telah menyajikan laporan keuangan yang tidak sesuai dengan kondisi keuangan perusahaan sebenarnya dan terdapat indikasi kelalaian yang dilakukan KAP dalam proses audit laporan keuangan pada anak usaha Grup Columbia tersebut (CNBC Indonesia, 2018). Jadi bukan jaminan KAP yang masuk dalam kategori KAP BIG4 memiliki kualitas audit yang lebih baik dibandingkan KAP NonBIG4 didalam menemukan kecurangan pelaporan keuangan.

\section{Auditor Switching terhadap Kecurangan Pelaporan Keuangan}

Berdasarkan hasil penelitian pada Tabel 5 . menunjukkan bahwa ada nilai signifikansi uji pengaruh auditor switching terhadap kecurangan pelaporan keuangan sebesar 0,004 dengan nilai beta positif 19.487. Hal ini menunjukkan bahwa $\mathrm{H} 2$ diterima. Temuan ini menyiratkan bahwa perusahaan yang melakukan auditor switching secara sukarela maka semakin tinggi kecurangan pelaporan keuangan. Begitu juga sebaliknya, perusahaan yang tidak melakukan auditor switching secara sukarela maka semakin rendah kecurangan pelaporan keuangan perusahaan. Manajemen lebih cenderung mengubah auditornya untuk mengantisipasi beberapa masalah agensi. Perusahaan melakukan auditor switching sebagai suatu bentuk menghilangkan atau menghapus jejak kecurangan yang ditemukan oleh auditor sebelumnya (Bawekes et al., 2018). Kecenderungan ini mendorong perusahaan untuk melakukan auditor switching secara sukarela untuk menutupi kecurangan pelaporan keuangan yang ditemukan oleh auditor sebelumnya (Septriani, 2018).

Perusahaan yang melakukan kecurangan lebih sering melakukan auditor switching secara sukarela, hal ini disebabkan manajemen perusahaan cenderung mengurangi kemungkinan terdeteksinya kecurangan pelaporan keuangan oleh auditor yang lama (Septriani, 2018). Perusahaan yang melakukan kecurangan mempunyai frekuensi auditor switching lebih sering dikarenakan untuk mengurangi kemungkinan terdeteksinya kecurangan pelaporan keuangan pihak manajemen perusahaan. Beberapa penelitian telah menunjukkan bahwa kejadian kegagalan audit setelah adanya auditor switching. Hasil penelitian ini mendukung penelitian Lou dan Wang, (2009) yang menunjukkan bahwa auditor switching berkorelasi positif dengan kemungkinan terjadinya kecurangan. Sehingga dapat disimpulkan bahwa dengan adanya auditor switching secara sukarela, kecurangan pelaporan keuangan semakin tinggi.

Pengaruh Kepemilikan Institusional sebagai variabel pemoderasi pada hubungan Kualitas Auditor dan Kecurangan Pelaporan Keuangan

Berdasarkan hasil penelitian Tabel 5 nilai signifikansi pengaruh kepemilikan institusional secara langsung terhadap kecurangan pelaporan keuangan sebesar 0.585 dengan nilai beta -0153 menunjukkan bahwa kepemilikan institusional secara langsung tidak berpengaruh secara signif- 
ikan terhadap kecurangan pelaporan keuangan. Hasil penelitian ini bertentangan dengan hasil penelitian Alves, (2012) yang menjelaskan bahwa kepemilikan institusional berpengaruh dalam mengurangi terjadinya kecurangan pada laporan keuangan. Namun demikian, hasil penelitian Wu et al. (2016) menjelaskan bahwa peran kepemilikan institusional yang efektif dalam pemantauan manajemen perusahaan dan dengan kepemilkan saham yang besar mampu membuat insiden kecurangan pada laporan keuangan perusahaan menjadi rendah. Nilai signifikansi kepemilikan institusional sebagai variabel moderasi pada hubungan kualitas audit terhadap kecurangan pelaporan keuangan pada penelitian ini sebesar 0,120 dengan nilai beta negatif -13.762 sehingga H3 ditolak. Hal ini membuktikan bahwa kepemilikan institusional secara langsung maupun sebagai variabel moderating tidak berpengaruh dalam memperlemah pada hubungan antara kualitas audit terhadap kecurangan pelaporan keuangan.

Hasil penelitian Zureigat, (2011) menunjukkan bahwa kepemilikan institusional mampu memainkan peran aktif dlam pemantauan dan mendisiplinkan kebijaksanaan manajerial dan dalam mengendalikan proses pelaporan. Kepemilikan institusional bertindak sebagai pengawas memiliki partisipasi dalam perusahaan, namun demikian tidak mampu mengurangi kecurangan pelaporan keuangan secara langsung dan tidak mampu memoderasi pada hubungan kualitas audit terhadap kecurangan pelaporan keuangan dikarenakan pengujian secara langsung kualitas audit yang diukur dengan KAP BIG4 dan Non-BIG4 tidak mempengaruhi kecurangan pelaporan keuangan. Begitu juga, walaupun dilakukan pengujian dengan menempatkan variabel moderating kepemilikan institusional masih menunjukkan hal yang sama bahwa kepemilikan institusional tidak berpengaruh secara signifikan pada hubungan kualitas audit terhadap kecurangan pelaporan keuangan.

Pengaruh Kepemilikan Institusional sebagai variabel pemoderasi pada Hub- ungan Auditor Switching dan Kecurangan Pelaporan Keuangan

Hasil penelitian pada Tabel 5. nilai signifikansi pengaruh kepemilikan institusional secara langsung terhadap kecurangan pelaporan keuangan sebesar 0.585 dengan nilai beta -0153 menunjukkan bahwa kepemilikan institusional tidak berpengaruh secara langsung terhadap kecurangan pelaporan keuangan. Nilai signifikansi kepemilikan institusional sebagai variabel moderating pada hubungan auditor switching terhadap kecurangan pelaporan keuangan sebesar 0.095 dengan nilai beta negatif -0.123 . Nilai signifikansi $0.095<0.10$ maka dapat disimpulkan bahwa H4 diterima pada tingkat signifikansi 0.10. Dengan demikian, semakin tinggi kepemilikan institusional maka semakin memperlemah pada hubungan antara auditor switching terhadap kecurangan pelaporan keuangan. Kepemilikan institusional yang semakin tinggi berperan memberikan tekanan kepada pihak manajemen perusahaan untuk tidak melakukan auditor switching secara sukarela. Dengan tidak adanya auditor switching secara sukarela, perusahaan tidak dapat menyembunyikan jejak kecurangan yang telah ditemukan auditor sebelumnya sehingga tingkat kecurangan pelaporan keuangan semakin menurun. Perusahaan yang melakukan auditor switching secara sukarela dapat menyembunyikan jejak kecurangan yang ditemukan auditor sebelumnya sehingga (Bawekes et al., 2018). Begitupun sebaliknya, semakin rendah tingkat kepemilikan institusional maka semakin rendah dalam berperan memberikan tekanan kepada pihak manajemen perusahaan untuk melakukan auditor switching secara sukarela.

Hasil penelitian $\mathrm{Wu}$ et al. (2016) menyatakan bahwa kepemilikan institusional dengan proporsi yang besar memiliki tingkat kecurangan lebih rendah. Kepemilikan institusional sebagai pemilik terbesar dalam perusahaan mempunyai wewenang dalam menentukan dan menekan frekuensi auditor switching secara sukarela. Kepemilikan institusional dengan persentase kepemilikan saham yang besar mempunyai kesempatan, sum- 
ber daya, dan kemampuan dalam mendisiplinkan, mengawasi sikap opportunis manajemen dalam pembuatan laporan keuangan dan mempengaruhi keputusan manajer diperusahaan (Yang et al., 2009). Pihak manajemen akan bekerja sesuai dengan kepentingan principal, sehingga manajemen perusahaan akan melakukan yang terbaik untuk kepentingan perusahaan. Kemampuan kepemilikan institusional dapat mempengaruhi manajemen tergantung pada persentase investasi mere$\mathrm{ka}$, proporsi saham yang dipegang investor institusional berpengaruh terhadap tata kelola perusahaan, resiko, profitabilitas dan sebagai mekanisme pemantauan dalam mencegah kecurangan (Hutchinson et al., 2012). Dengan adanya tingkat kepemilikan institusional yang semakin tinggi dapat menekan auditor switching secara sukarela tidak terjadi. Perusahaan dengan melakukan auditor switching sesuai peraturan/ rotasi auditor secara wajib maka auditor dapat lebih mendalami perusahaan sehingga dapat mendeteksi dan mengungkap adanya kecurangan pelaporan keuangan. Dengan demikian, tindakan kecurangan pelaporan keuangan semakin menurun. Hasil penelitian ini membuktikan bahwa kepemilikan institusional mampu menjadi variabel moderating pada hubungan antara auditor switching terhadap kecurangan pelaporan keuangan.

\section{SIMPULAN}

Simpulan dari penelitian ini adalah auditor switching memiliki pengaruh signifikan positif terhadap kecurangan pelaporan keuangan. Kepemilikan institusionl sebagai variabel moderating secara signifikan dapat memperlemah pada hubungan antara auditor switching terhadap kecurangan pelaporan keuangan. Namun demikian, kualitas audit tidak memiliki pengaruh yang signifikan terhadap kecurangan pelaporan keuangan. Kepemilikan institusional juga tidak mampu memperkuat pada hubungan antara pengaruh kualitas audit terhadap kecurangan pelaporan keuangan.

Implikasi teori dalam penelitian ini adalah hasil penelitian ini mendukung teori yang ada. Sedangkan implikasi praktis dari hasil penelitian ini adalah pentingnya peran kepemilikan institusional sebagai pengawas dan pengendalian dalam hal ini menekan auditor switching secara sukarela untuk mengurangi kecurangan pelaporan keuangan. Variabel kontrol leverage dan profitabilitas berpengaruh secara signifikan pada perusahaan yangmelakukan kecurangan pelaporan keuangan. Perusahaan dengan leverage dan profitabilitasnya yang semakin tinggi, maka semakin rendah kecurangan pelaporan keangan. Namun demikian, variabel kontrol ukuran perusahaan dan current ratio tidak berpengaruh terhadap kecurangan laporan keuangan. Sehingga, dapat disimpulkan bahwa semakin tinggi atau rendahnya ukuran perusahaan dan current ratio perusahaan tidak mempengaruhi perusahaan melakukan kecurangan pelaporan keuangan.

\section{KETERBATASAN DAN SARAN}

Penelitian ini hanya menggunakan variabel kepemilikan institusional sebagai variabel moderating dalam menguji pada hubungan antara kualitas audit dan audit switching terhadap kecurangan pelaporan keuangan serta menggunakan motode kuantitatif. Hasil penelitian ini tidak berhasil membuktikan bahwa kualitas audit berpengaruh terhadap kecurangan pelaporan keuangan.

Penelitian selanjutnya diharapkan dapat menggunakan variabel lain diluar variabel penelitian seperti mekanisme good corporate governance, budaya atau faktor situasional lainnya sehingga dapat menjelaskan lebih lanjut dan tepat terkait kecurangan pelaporan keuangan. Pengembangan penelitian selanjutnya dapat menggunakan data primer dan dengan pendekatan kualitatif sehingga dapat menjelaskan secara lebih rinci dan komprehensif terkait terkait kecurangan laporan keuangan. Saran selanjutnya, dapat menggunakan pengukuran yang lain selain kualitas audit yaitu accrual lancar seperti pada penelitian Manry pada tahun 2008. Berdasarkan hasil penelitian ini membuktikan semakin tinggi auditor switching secara sukarela maka semakin menurunkan tingkat kecurangan pelaporan keuangan. Hasil penelitian ini mendukung PP Nomor 
20 Tahun 2015 tentang Praktik Akuntan Publik. Hal ini perlu menjadi perhatian khusus bagi pihak regulator yang berperan sebagai pembuat peraturan terkait pembatasan jasa audit.

\section{DAFTAR PUSTAKA}

Aggarwal, R., Hu, M., \& Yang, J. (2014). Fraud, market reaction, and role of institutional investors in Chinese listed firms. The Journal of Portfolio Management, 41(5), 92-109.

Alves, S. (2012). Ownership structure and earnings management: Evidence from Portugal. Australasian Accounting, Business and Finance Journal, 6(1), 5774.

Association of Certified Fraud Examiners. (2018). Report to the Nations on Occupational Fraud and Abuse.

Bawekes, H. F., Simanjuntak, A. M., \& Daat, S. C. (2018). Pengujian Teori Fraud Pentagon Terhadap Fraudulent Financial Reporting. Jurnal Akuntansi Dan Keuangan Daerah, 13(1), 114-134.

Beneish, M., Lee, C., \& Nichols, D. C. (2012). Fraud detection and expected returns. Diakses dari https://ssrn.com/ abstract $=1998387$.

CNBC Indonesia. (2018). Ada apa dengan deloitte dan snp finance ini penjelasannya. Diakses dari https:// www.cnbcindonesia.com/ market/20180802101243-17-26563/ ada-apa-dengan-deloitte-dan-snpfinance-ini-penjelasannya.

Gerayli, M. S., Yanesari, A. M., \& Ma'atoofi, A. R. (2011). Impact of Audit Quality on Earnings Management: Evidence from Iran. International Research Journal of Finance \& Economics, 66(66), 77 -84 .

Guna, W. I., \& Herawaty, D. A. (2010). Pengaruh Mekanisme Good Corporate Governance, Independensi Auditor, Kualitas Audit Dan Faktor Lainnya Terhadap Manajemen Laba. Bisnis Dan Akuntansi, 12(1), 53-68.

Handayani, R. S., Agustono, D., \& Rachadi, D. (2009). Pengaruh Ukuran Perusahaan Terhadap Manajemen Laba. Jurnal Bisnis Dan Akuntansi, 11(1), 3356.

Hutchinson, M. R., Seamer, M., \& Chapple, L. J. (2012). Institutional investors, risk/ return and corporate governance. Practical Lessons from the Global Financial Crisis. Dipresentasikan pada acara Accounting \& Finance Association of Australia New Zealand Confer- ence, Melbourne.

Jensen, M. C., \& Meckling, W. H. (1976). Theory of the firm: Managerial behavior, agency costs and ownership structure. Journal of Financial Economics, 3(4), 305-360.

Lawrence, A., Minutti-Meza, M., \& Zhang, P. (2011). Can Big 4 versus non-Big 4 differences in audit-quality proxies be attributed to client characteristics? The Accounting Review, 86(1), 259286.

Lennox, C., \& Pittman, J. (2010). Auditing the auditors: Evidence on the recent reforms to the external monitoring of audit firms. Journal of Accounting and Economics, 49(1-2), 84-103.

Lou, Y., \& Wang, M. (2009). Fraud Risk Factor of The Fraud Triangle Assessing The Likelihood Of Fraudulent Financial Reporting. Journal of Business \& Economics Research, 7(2), 61-78.

Miyajima, H., \& Hoda, T. (2015). Ownership Structure and Corporate Governance: Has an Increase in Institutional Investors' Ownership Improved Business Performance?. Public Policy Review, 11 (3), 361-393.

Pamungkas, I. D., Ghozali, I., \& Achmad, T. (2017). The effects of the whistleblowing system on financial statements fraud: Ethical behavior as the mediators. International Journal of Civil Engineering and Technology, 8(10), 15921598.

Rezaee, Z. (2007). Corporate governance post-Sarbanes-Oxley: Regulations, requirements, and integrated processes. doi.org/10.1002/9781119201335.ch1.

Rezaee, Z., \& Davani, G. (2013). Does Financial Reporting Fraud Recognize Borders? Evidence from Bank Fraud in Iran. Journal of Forensic \& Investigative Accounting, 5(2), 224-238.

Santiso, C. (2016). 3 ways for institutional investors to fight corruption. Diakses dari https://www.weforum.org/ agenda/2016/10/3-ways-for-

institutional-investors-to-fight corruption.

Septriani, Y. (2018). Mendeteksi Kecurangan Laporan Keuangan dengan Analisis Fraud Pentagon. Jurnal Politeknik Caltex Riau, 11(1), 11 $-23$.

Shah, S. Z. A., Zafar, N., \& Durrani, T. K. (2009). Board composition and earnings management an empirical evidence form Pakistani Listed Companies. Middle Eastern Finance and Economics, 3(29), 30-44. 
Skousen, C. J., Smith, K. R., \& Wright, C. J. (2009). Detecting and predicting financial statement fraud: The effectiveness of the fraud triangle and SAS No. 99. In Corporate governance and firm performance. Emerald Group Publishing Limited., 53-81.

Smaili, N., \& Labelle, R. (2009). Preventing and Detecting Accounting Irregularities: The Role of Corporate Governance. Diakses dari https://ssrn.com/ abstract $=1324143$.

Suyanto, S. (2009). Fraudulent financial statement: evidence from statement on auditing standard no. 99. Gadjah Mada International Journal of Business, 11(1), 117-144.

Tsipouridou, M., \& Spathis, C. (2012). Earnings management and the role of auditors in an unusual IFRS context: The case of Greece. Journal of International Accounting, Auditing and Taxation, 21(1), 62-78.

Wells, J. T. (2011). Financial statement fraud casebook: baking the ledgers and cooking the books. New York: John Wiley \& Sons.

Werastuti, D. N. S. (2015). Analisis Prediksi
Potensi Risiko Fraudulent Financial Statement Melalui Personal Financial Need dan Auditor Switching. Jurnal Ilmiah Akuntansi Dan Bisnis, 10(1), 3744.

Wu, W., Johan, S. A., \& Rui, O. M. (2016). Institutional investors, political connections, and the incidence of regulatory enforcement against corporate fraud. Journal of Business Ethics, 134 (4), 709-726.

Yang, W. S., Chun, L. S., \& Ramadili, S. M. (2009). The effect of board structure and institutional ownership structure on earnings management. International Journal of Economics and Management, 3(2), 332-353.

Yasar, A. (2013). Big Four auditors' audit quality and earnings management: Evidence from Turkish Stock Market. International Journal of Business and Social Science, 4(17), 153-163.

Zureigat, Q. M. (2011). The effect of ownership structure on audit quality: Evidence from Jordan. International Journal of Business and Social Science, 2 (10), 38-46. 